\title{
Engine Performance and Exhaust Gas Emission of a Gasoline Engine using Ethanol-Gasoline Blended from Bioethanol of DurioZibethinus Seed and SalaccaZalacca
}

\author{
Leo Van Gunawan ${ }^{1}$, Marwan Effendy ${ }^{2, *}$ \\ ${ }^{1}$ Department of Mechanical Engineering, Universitas Sains Al-Quran, Indonesia, 56351. \\ ${ }^{2}$ DepartmentofMechanicalEngineering,UniversitasMuhammadiyahSurakarta,Indonesia, 57102. \\ Marwan.Effendy@ums.ac.id.
}

\begin{abstract}
The study was to evaluate the performance and the exhaust gas emissions of an internal combustion engine on various blended fuel between gasoline and bioethanol. The engine performance was presented by torque and power, whereas the emission was illustrated by carbon monoxide (CO) and unburned hydrocarbon (HC). Two types of bioethanol were made from raw materials of Duriozibethinus and SalaccaZalacca, respectively. The first step of investigation was begun by producing both two types of bioethanol up to reaching the purity of the product more than 99\%. It involved a gradual process starting from liquefaction, scarification, fermentation, distillation and purifying ethanol by dehydration. The second step was to prepare three various blended fuel by mixing the bioethanol and pure gasoline fuel. The compositions of blended fuel were E05 (95\% gasoline - 5\% bioethanol), E10 (90\% gasoline $10 \%$ bioethanol), and E15 (85\% gasoline - $15 \%$ bioethanol) for both raw materials. The next step, each blended fuel was tested using a four-stroke engine with fuel injection system to investigate the engine performance such as torque and power on various engine speed between 0 $10,000 \mathrm{rpm}$. The common operational engine speed ranging from 1500 - $4000 \mathrm{rpm}$ was observed for collecting emissions data. The results indicated that both $\mathrm{CO}$ and $\mathrm{HC}$ emissions could be slightly reduced by the application of blended fuel. The torque and power could be maintained within relatively high performance as well as the use of pure gasoline fuel.
\end{abstract}

Key words: Bioethanol, Duriozibethinus, SalaccaZalacca Alternative Fuel, Gasoline engine, Blended fuel.

\section{INTRODUCTION}

In the last decade, energy sourced from fossil fuels is to be the mainstay to sustain various production processes and the driving force of vehicles. The rapid development of the industry and the growth of vehicles requires sufficient energy to support its operation. Along with the growth of population in the worlds, the need of overall energy will also be increasing in line with the growth rate. Of course, the growth triggers the availability of transportation facilities such as vehicles and other transportation mode. On the other hand, energy reserves in the form of fossil fuels are to be less-and-less due to daily exploration.
The efforts to have new alternative fuels for internal combustion engines have also been carried out in recent decades. New and renewable energy is to be a global issue which interest for scientists. The production of bioethanol from natural materials is to be challenging in the context of fossil fuel substitution which is allegedly less friendly to the environment [1]. Bioethanol is flammable and has a high heating value. The heating value of bioethanol is approximately $2 / 3$ of the heating value of gasoline. The content of bioethanol is soluble and can be used in the process of oxygenation of gasoline fuels to reduce emissions so that the exhaust gas is cleaner and more environmentally friendly [2]. With various advantages, bioethanol is a variant of biofuels being a promising alternative to produce an environmentally friendly combustion process. Similarly, a researcher stated that bioethanol is potential to replace gasoline fuel because of its low emission effects [3].

Duriozibethinus and SalaccaZalacca are organic materials that have great potential to be developed as alternative fuels. Duriozibethinus contributes to produce waste in the form of skins and seeds agglomerate which are abundant to around $42-47 \%$ and 20-25\%, respectively [4]. Meanwhile, the percentage ratio of fruit, skin and seeds is sequent to 56$65 \%, 10-14 \%$ and $25-30 \%$ [5]. This waste sometimes actually disturbs the surrounding environment because it has not been used totality. During this time, its skins are usually only used as a basis for making briquettes, while the seeds are only thrown away or replanting. Some literature noted that carbohydrates contained in durian seeds is amount $43.6 \%$, while zalacca contains cellulose and hemicellulose carbohydrates by $7.54 \%$. Carbohydrates contain amylum which is the most important substance in making bioethanol. Amylum from duriozibethinus seeds can be ideally converted into ethanol through several stages of processing, namely the process of making flour, liquefication, saccharification, fermentation, distillation and dehydration. The criteria of Fuel Grade Ethanol (FGE) is commonly used to evaluate the purity of ethanol (>99\%). The purity of bioethanol with more than $99 \%$ can be generally used as a mixture of gasoline fuel.

In general, the content of fuel directly affects the engine performance and exhaust gas emissions such as torque and power, thermal and volumetric efficiency, mean effective pressure, specific fuel consumption, exhaust gas temperature including emissions $\left(\mathrm{CO}, \mathrm{CO}_{2}, \mathrm{NO}_{\mathrm{x}}, \mathrm{SO}_{\mathrm{x}}\right.$, 
unburned HC). An experimental study using ethanolunleaded gasoline blended confirmed both discrepancies of engine performance and exhaust emissions [6]. In combustion process of vehicle engines, the addition of ethanol up to $3 \%$ in pure gasoline fuel is able to reduce the emissions of $\mathrm{CO}$ and $\mathrm{HC}$ up to $20 \%$ and $5.27 \%$, respectively [7]. Similar findings were revealed by other researchers that evaluate the addition of ethanol up to $10 \%$ in a blended gasoline fuel [8]. It was able to reduce both exhaust emission between $63-73 \%$ and $26-45 \%$, respectively. An experiment by mixing ethanol up to $30 \%$ into gasoline proved that the addition of $20 \%$ ethanol can significantly minimize $\mathrm{CO}$ and $\mathrm{HC}$ emissions. The addition of ethanol triggers an increase the oxygen contents in the blended fuel, so that it can diminish emissions of incomplete combustion gases [9][10]. Furthermore, the addition of bioethanol from cassava up to $20 \%$ noted that oxygen in bioethanol and the speed of the spark plug flame is able to increase the perfection of the combustion process so that the engine efficiency increases. Both torque and power could be increased with lower specific fuel consumption (BSFC), and $\mathrm{CO}$ and $\mathrm{HC}$ emissions could also be reduced.

Previously, Antonietta et al. [11] stated that mixing bioethanol with gasoline fuel triggers an increase the oxygen contents and reduces emissions from incomplete combustion processes. A recent research carried out by Sakthivel et al. [12] found that a mixing up to $30 \%$ ethanol into gasoline decreases $\mathrm{CO}$ and NOx emissions, but hydrocarbon emissions increases marginally. In line with some of these studies, Chen et al. [13] noted that the increasing composition of bioethanol in gasoline fuel causes a significant emission reduction, although an addition of up to $40 \%$ influences the instability of idle conditions because of a lean mixture of fuel and air.

In addition to reducing levels of exhaust emissions, the use of a mixture of fuel with bioethanol is also able to provide a combustion effect with high vehicle engine performance. Some research facts noted that combustion of ethanol mixture in gasoline is capable of having optimum performance [14][15] with high volumetric efficiency [16]. The use of ethanol-gasoline mixture up to $5 \%$ in an internal combustion engine triggers an increase of fuel consumption and octane number as a result of lower alcohol calorific value than pure gasoline [17].

On the other side, the use of blended gasoline fuel with ethanol increase in delivery ratio and scavenging efficiency. It causes the reduction of trapping efficiency and combustion temperature due to a rapid evaporation process of ethanol. The converging efficiency and consumption of gasoline fuel was also decreased [18]. A better achievement of thermal efficiency and reduction of emission could be significantly reached by adding hydrous ethanol in gasoline fuel [19].

In connection with the literature review discussed, the current study focuses on evaluating the exhaust emissions and the engine performance due to the use of blended fuel between gasoline and bioethanol from Duriozibethinus and Salaccazalacca. The mixture variations used are E05 (95\% gasoline and 5\% bioethanol), E10 (90\% gasoline and 10\% bioethanol) and E15 (85\% gasoline and 15\% bioethanol).
The mixing process refers to the composition that has been done by other researchers such as Najafi et al. [20] and Sebayang et al. [3]. The research parameters are torque, power, and $\mathrm{HC}$ and $\mathrm{CO}$ emissions. The purpose of the current study is to evaluate the process of making bioethanol from Duriozibethinus and Salaccazalacca as an alternative fuel for gasoline mixture and its effect on vehicle engine emissions and performance.

\section{EXPERIMENTAL FACILITY AND METHOD}

This research was performed in two stages, namely the production of bio-ethanol and the blended fuel testing of the gasoline engine to collect data of both engine performances and emissions in various fuel compositions. The raw materials of bio-ethanol were organic wastes of Duriozibethinus and Salaccazalacca from local plants in Indonesia. Engine performance and exhaust gas emissions were carried out on a four-stroke single-cylinder motorized vehicle with a capacity of $100 \mathrm{cc}$ using pure fuel and blended fuel with both bioethanol. As previously used in another experiment, dynotest sport devices smart power SP 1 and engine gas analyser were used for both scenarios of data collection [21].

The production process of bioethanol involves a gradual process such as liquefaction, saccharification, fermentation, distillation, and dehydration. Both Duriozibethinus and Salaccazalacca theoretically contain carbohydrate up to $43.6 \%$ and $7.54 \%$, respectively. Carbohydrates contain glucose which is the most important substance in making bioethanol. The steps in making bioethanol, namely 1) Duriozibethinus and Salaccazalacca were carefully washed using pure water, 2). each material was produced into wet flour with a grater machine, 3) the production of wet flour was dried to reduce their humidity for getting dry flour, 4). Dry flour liquefication process at a temperature $>90^{\circ} \mathrm{C}$ within 30 minutes to convert carbohydrates into glucose. In the liquefication process, it was necessary to add the alphaamylase enzyme to break down the structure of the chemical flour into complex glucose liquids such as soups. The addition of the glucosyl amylase enzyme was needed in the scarification process.

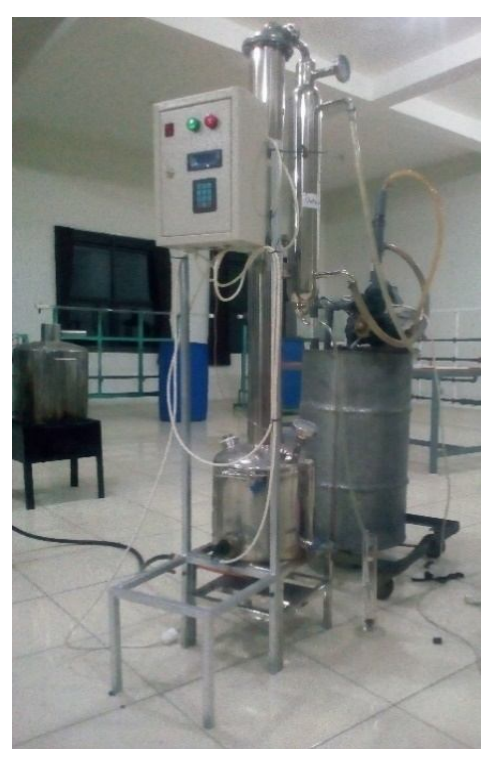

Figure 1: Dehydrator. 
An anaerobic fermentation process was carried out by inserting saccharified product flour porridge into the fermenter container. Yeast and urea powder were added to the porridge. The fermenter tube was stored up to 7 days at room temperature to decompose glucose into ethanol and $\mathrm{CO} \square$. The fluid product from the fermentation process of the flour porridge was filtered and put into a distillation to separate ethanol from water in the distillation process. With this process, the level of bioethanol produced could reduce the water contents up to the quality of approximately $92 \%$. To improve the quality of bioethanol to meet the criteria of fuel-grade ethanol, the purification process using a dehydrator machine was needed to reach more than $99 \%$. The dehydration process played an important role to have the highest quality of bio-ethanol, so the final products could be blended with gasoline fuel.Figure 1 illustrates the installation of the dehydrator used in the purification process.

Figure 2 shows the detailedcomponents of dehydrator and flow purification process from $92 \%$ to the highest quality of ethanol. Zeolite-stone and zeolite-sand were utilized in the installation for filtering and purifying process, respectively. Water content of bioethanol was absorbed before continuing the step of purification. The final process, bioethanol was condensed in a vertical condenser to reach a fuel grade ethanol (>99\%).
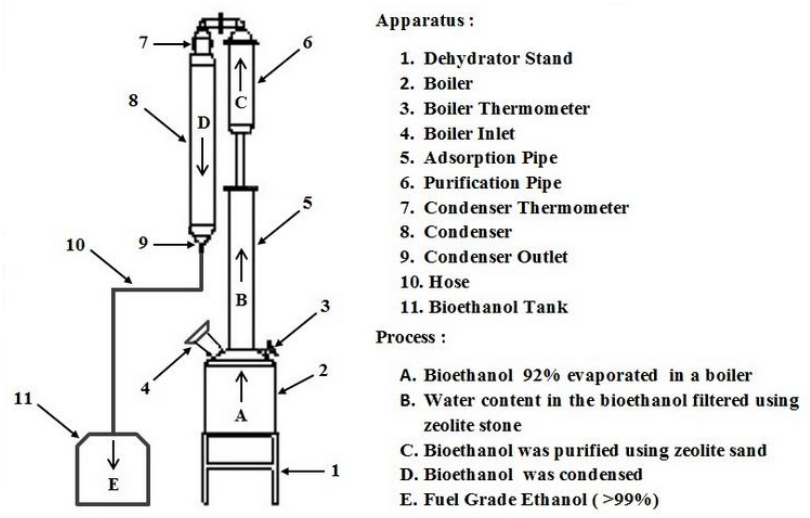

Figure 2: Dehydrator Componentsand Purification Process

Based on the final product of bioethanol with the purity of bioethanol more than $99 \%$, both testing of engine performance and emissions could be realised in various fuel composition. The scenarios carried out by Sebayang et al. [3]were adopted to perform the composition of fuel mixtures. The blended fuel was varied at three various compositions, i.e. E05 (95\% gasoline fuel and 5\% bioethanol); E10 (90\% gasoline fuel and 10\% bioethanol); E15 (85\% gasoline fuel and $15 \%$ bioethanol). Each blended fuel was applied in a four-stroke engine with a fuel injection system to observe the engine performance such as torque and power on various engine speed between 0 $10,000 \mathrm{rpm}$. The engine performance due to the use of all blended fuel compositions were investigated to evaluate overall performance, including the exhaust gas emissions. Each experiment was exactly kept at the same procedure to ensure the accuracy of measurement data. Testing for emissions covered hydro-carbon (HC) and carbonmonoxide (CO) using STAR GAS 898. A standard of ISO
3929 was used as a reference for emissions testing. The common operational engine speed ranging from 1500 $4000 \mathrm{rpm}$ was tested for collecting emissions data. A detailed experimental apparatus can be seen in Figure 3.

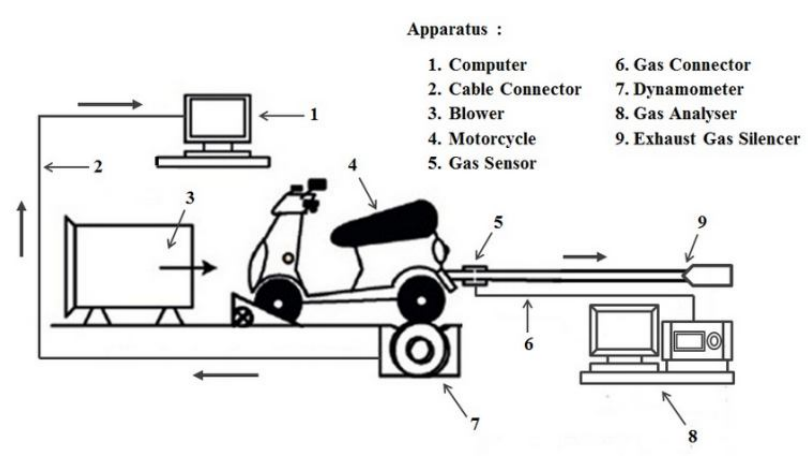

Figure 3: Experimental Apparatus.

\section{RESULTS AND DISCUSION}

The experimental research has been worked out to investigate the engine performances and the exhaust emissions on various blended fuel compositions. Bioethanol made from organic wastes of Duriozibethinus seed and Salaccazalacca were used to add to gasoline fuel ranging from $5 \%$ to $15 \%$.

\subsection{Engine Performance}

Figure 4 and Figure 5 give the engine performances against the operating engine speed at different blended fuel compositions, in comparison with the experimental measurements carried out by Sebayanget al. [3]. In terms of the engine speed range, the current study was successfully investigated within the extensive scopes, compared to another research. It has been recognized that both performance trends are consistent with available measurement data. The tendency of torque and power for various fuels is similar. In terms of the achievement of torque and power, the use of blended fuels is reasonable compared to pure gasoline fuel. Each adding the concentration of bioethanol into pure gasoline fuel decreases their lower heating value (LHV), molar weight and laminar flame speed. The stoichiometric of air-fuel ratio (AFR) in a mixture of blended fuel is also reduced by adding the concentration of bio-ethanol. As noted in open literature, the product of bioethanol made from plants has a lower heating value compared to gasoline fuel. It is in contrast with several properties such as density, research octane number (RON), and latent heat of vaporisation where bio-ethanol is to be higher compared to pure gasoline fuel.

From Figure 4, the engine torques also increase rapidly with operating engine speed up to 2,000 rpm. Its decrease gradually after reaching the peak point at around 22-24 Nm. The turbulence flow entered the combustion chamber triggers the increase of the mixing process between air and fuel which influence the propagation of flame speed. The increase of engine speed causes the increase of both friction and heat losses, including triggers incomplete combustion that impact to the reduction of torque after attaining peak points at 2,000 rpm as indicated in Figure 5. To be noted that the basic property of laminar flame speed is different 
for each various blended fuel composition. The increase of bioethanol into blended fuel indirectly decelerates an overall combustion process due to reduction of the laminar flame speed. A lower heating value of blended fuel causes the reduction of torque resulted. It can be seen that torques resulted from the use of blended fuel is lower than torque generated by the use of pure gasoline fuel. Investigation of the blended fuel with both bioethanol up to $15 \%$ indicate that it can be considered acceptable to maintain at high performances

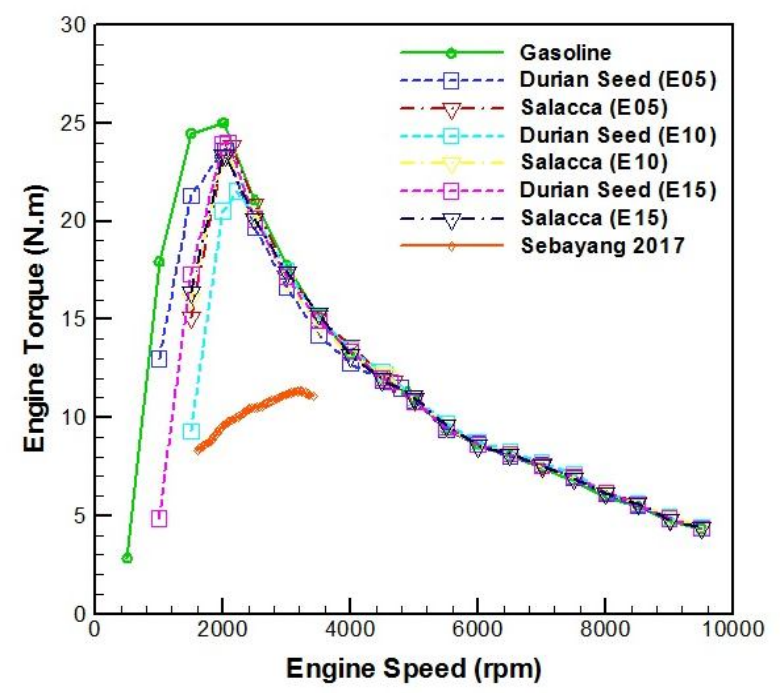

Figure 4: Torque

Theoretically, the engine power is proportional to the engine torque due it is to be related to the breaking load. From Figure 5, the engine powers increase rapidly with operating engine speed up to $2,000 \mathrm{rpm}$. The engine powers increase moderately between 2,000 - 4,400 rpm, and it decreases slowly after attaining the peak point. Upand-down curves occur in a range of 4,400-9,400 rpm. The basic properties of latent heat of vaporisation for blended fuel is to be much higher by adding the concentration of bioethanol that absorb more energy and reduce an intake air temperature. It gives an advance condition to maintain torque and power in high level.

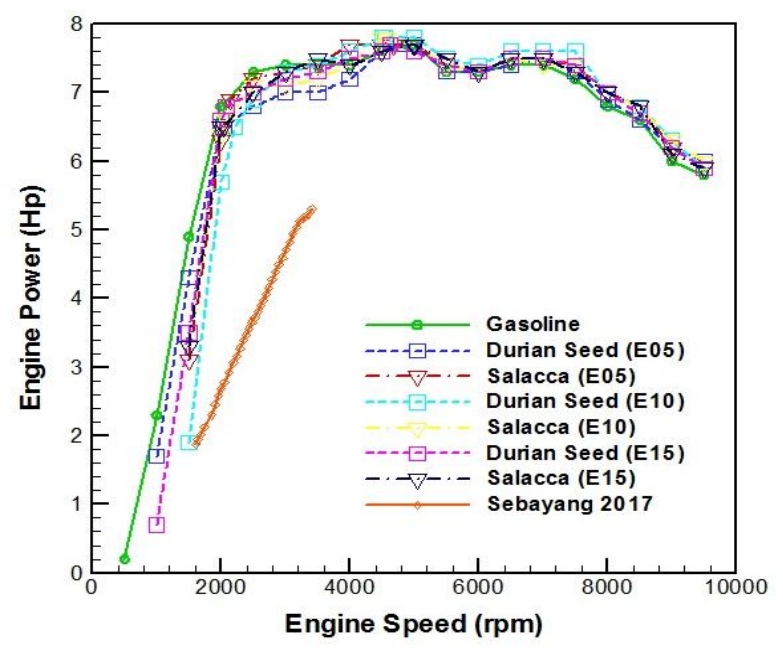

\subsection{Exhaust Gas Emissions}

Figure 6 and Figure 7 show the exhaust emissions against the operating engine speed at different blended fuel compositions, in comparison with the experimental measurements carried out by another researcher. It has been found that both emissions trends decrease with increasing the engine speed. It is consistent to available measurement by another researcher, although both are insignificant discrepancies. It is most likely due to the difference of experimental setup and the bioethanol quality between them.

Hydrocarbon (HC) is an organic compound consisting entirely of carbon and hydrogen due to unburned gasoline fuel inside the combustor chamber. From Figure 6, the HC emissions reduce significantly with operating engine speed up to $2,000 \mathrm{rpm}$. It decelerates moderately between $2,000-$ $4,000 \mathrm{rpm}$. The reduction of $\mathrm{CO}$ emissions also achieves with increasing the operating engine speed from 1,500 4,000 rpm, as presented in Figure 7. It represents a complete combustion in higher engine speed. The propagation of flame speed increases with raising the engine speed that triggers the turbulence flow entered the combustion chamber. The mixing process between air and fuel is more homogeneous that contributes more complete combustion to have a better transformation of $\mathrm{CO}$ to $\mathrm{CO}_{2}$. The $\mathrm{CO}$ emission is formed by the partial oxidation due to not enough oxygen in reaction to produce $\mathrm{CO}_{2}$.

The reduction of both $\mathrm{HC}$ and $\mathrm{CO}$ emissions is to be related to the $\mathrm{O}_{2}$ substance of the blended fuel. The adding of bio-ethanol into gasoline fuel influences the oxygenated blends in the fuel. HC emissions tend to reduce due to the increase of the $\mathrm{O}_{2}$ contents. The presence of oxygen accelerates the flame propagation and combustion rate. Besides, it was allegedly tending to promote a complete combustion which affect in lowering HC emissions.

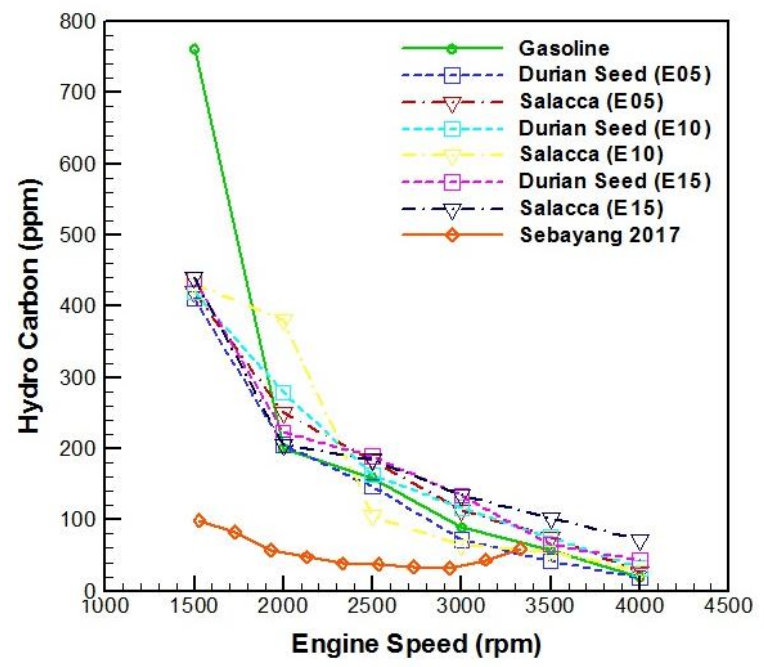

Figure 6: $\mathrm{HC}$ emission

Figure 5: Power 


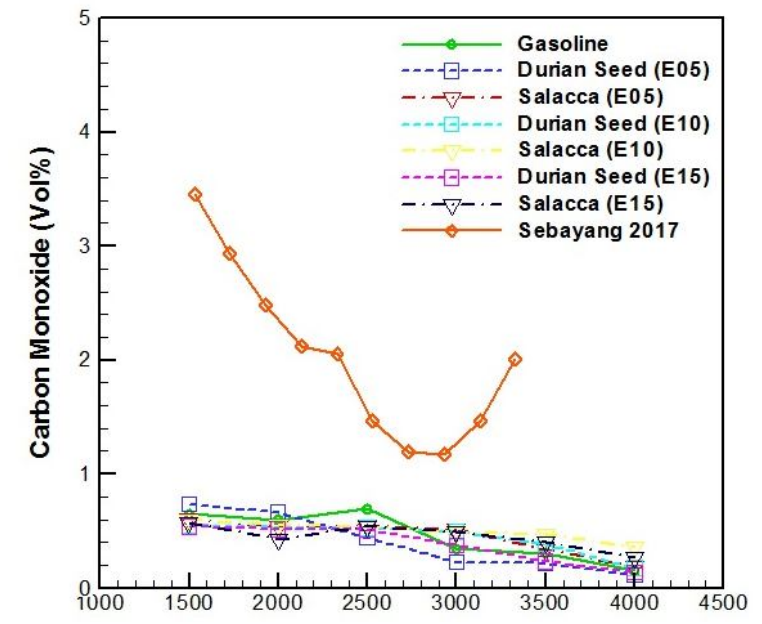

Figure 6: $\mathrm{CO}$ emission

\section{CONCLUSION}

This study is successful to produce bioethanol from Duriozibethinus and SalaccaZalacca up to the purity of product more than $99 \%$. Investigation on the use of three various blended fuel shows that the addition of bioethanol into mixing fuel plays an important role in the overall performance of an internal combustion engine. Both $\mathrm{CO}$ and $\mathrm{HC}$ emissions could be slightly reduced by the application of blended fuel between bioethanol and gasoline fuel. The torque and power could be maintained within relatively high performance as well as in the use of pure gasoline fuel. Both products of bioethanol also are more environmentally friendly. It means that both products of bioethanol can be considered acceptable as an alternative solution to substitute fuel in a gasoline engine.

\section{ACKNOWELDGEMENT}

The authors would like to acknowledge the facilities from Universitas Muhammadiyah Surakarta and Universitas Sains Al-Quran Indonesia in supporting the collaborative research between both of them.

\section{REFERENCES}

1. Demirbas, "Biofuels securing the planet's future energy needs," Energy Conversion Management, vol. 50, no. 9, pp. 2239-2249, 2009.

https://doi.org/10.1016/j.enconman.2009.05.010

2. S. Kumar, N. Singh, and R. Prasad, "Anhydrous ethanol : A renewable source of energy," Renewable and Sustainable Energy Reviews, vol. 14, no. 7, pp. 1830-1844, 2010. https://doi.org/10.1016/j.rser.2010.03.015

3. H. Sebayang et al., "Prediction of engine performance and emissions with Manihot glaziovii bioethanol - Gasoline blended using extreme learning machine," Fuel, vol. 210, pp. 914-921, 2017.

https://doi.org/10.1016/j.fuel.2017.08.102
4. T. Amid and H. Mirhosseini, "Optimisation of aqueous extraction of gum from durian (Durio zibethinus) seed: A potential, low cost source of hydrocolloid," Food Chemistry, vol. 134, no. 3, p. 1591, 2012. https://doi.org/10.1016/j.foodchem.2012.03.125

5. Arie, H. Kristianto, E. Demir, and R. D. Cakan, "Activated porous carbons derived from the indonesian snake fruit peel as anode materials for sodium ion batteries," Materials Chemistryand Physics, vol. 217, pp. 254-261, 2018.

6. M. Koç, Y. Sekmen, T. Topgul, and H. S. Yucesu, "The effects of ethanol - unleaded gasoline blends on engine performance and exhaust emissions in a spark-ignition engine," Renewable Energy, vol. 34, pp. 2101-2106, 2009.

https://doi.org/10.1016/j.renene.2009.01.018

7. H. Yang, T. Liu, C. Chang, and E. Lee, "Effects of ethanol-blended gasoline on emissions of regulated air pollutants and carbonyls from motorcycles," Applied Energy, vol. 89, no. 1, pp. 281-286, 2012. https://doi.org/10.1016/j.apenergy.2011.07.035

8. L. Li et al., "Exhaust and evaporative emissions from motorcycles fueled with ethanol gasoline blends," Science ofthe Total Environment, vol. 502, pp. 627-631, 2015. https://doi.org/10.1016/j.scitotenv.2014.09.068

9. P. Iodice, A. Senatore, G. Langella, and A. Amoresano, "Effect of ethanol - gasoline blends on $\mathrm{CO}$ and $\mathrm{HC}$ emissions in last generation SI engines within the cold-start transient: An experimental investigation," Applied Energy, vol. 179, pp. 182190, 2016.

10. P. Iodice, G. Langella, and A. Amoresano, "Ethanol in gasoline fuel blends : Effect on fuel consumption and engine out emissions of SI engines in cold operating conditions," Applied Thermal Engineering, vol. 130, pp. 1081-1089, 2018.

11. M. A.Costagliolaet al., "Performances and emissions of a 4-stroke motorcycle fuelled with ethanol / gasoline blends," Fuel, vol. 183, pp. 470-477, 2016. https://doi.org/10.1016/j.fuel.2016.06.105

12. P. Sakthivel, K. A. Subramanian, and R. Mathai, "Comparative studies on combustion, performance and emission characteristics of a two-wheeler with gasoline and $30 \%$ ethanol-gasoline blend using chassis dynamometer," Applied Thermal Engineering, vol. 146, pp. 726-737, 2019.

13. R. Chen, L. Chiang, C. Chen, and T. Lin, "Cold-start emissions of an SI engine using ethanol e gasoline blended fuel," Applied Thermal Engineering., vol. 31, no. 8-9, pp. 1463-1467, 2011.

14. M. Al-Hasan, "Effect of ethanol - unleaded gasoline blends on engine performance and exhaust emission," Energy Conversion Management, vol. 44, pp. 1547-1561, 2003. https://doi.org/10.1016/S0196-8904(02)00166-8

15. R. C. Costa and J. R. Sodré, "Hydrous ethanol vs. gasoline-ethanol blend: Engine performance and emissions," Fuel, vol. 89, no. 2, pp. 287-293, 2010.

16. Elfasakhany, "Exhaust emissions and performance of ternary iso-butanol e bio- methanol e gasoline and n-butanol e bio-ethanol e gasoline fuel blends 
in spark-ignition engines : Assessment and comparison," Energy, vol. 158, pp. 830-844, 2018.

17. M. Eyidogan, A. N. Ozsezen, M. Canakci, and A. Turkcan, "Impact of alcohol - gasoline fuel blends on the performance and combustion characteristics of an SI engine," Fuel, vol. 89, no. 10, pp. 2713-2720, 2010. https://doi.org/10.1016/j.fuel.2010.01.032

18. M. Ghazikhani, M. Hatami, and B. Safari, "Experimental investigation of performance improving and emissions reducing in a two stroke SI engine by using ethanol additives," Propulsion and Power Research, vol. 2, no. 4, pp. 276-283, 2013. https://doi.org/10.1016/j.jppr.2013.10.002

19. X. Deng, Z. Chen, X. Wang, H. Zhen, and R. Xie, "Exhaust noise, performance and emission characteristics of spark ignition engine fuelled with pure gasoline and hydrous ethanol gasoline blends," Case Study in Thermal Engineering, vol. 12, pp. 55-63, 2018.

https://doi.org/10.1016/j.csite.2018.02.004

20. G. Najafi, B. Ghobadian, T. Tavakoli, D. R. Buttsworth, T. F. Yusaf, and M. Faizollahnejad, "Performance and exhaust emissions of a gasoline engine with ethanol blended gasoline fuels using artificial neural network," Applied Energy, vol. 86, no. 5, pp. 630-639, 2009.

https://doi.org/10.1016/j.apenergy.2008.09.017

21. S. Sunaryo, M. Effendy, S. Sarjito, and N. S. Kamarrudin, "Pyrolysis of plastic waste as an alternative fuels in spark ignition engine," International Journal of Emerging Trends Engineering Research, vol. 7, no. 11, pp. 454-459, 2019. https://doi.org/10.30534/ijeter/2019/097112019 